\title{
Protective regulation of the ACE2/ACE gene expression by estrogen in human atrial tissue from elderly men
}

\author{
A Bukowska ${ }^{1}$, L Spiller ${ }^{2}$, C Wolke $^{3}$, U Lendeckel ${ }^{3}, \mathrm{~S} \mathrm{Weinert}^{4}$, J Hoffmann ${ }^{5}$, P Bornfleth ${ }^{1}$, \\ I Kutschka ${ }^{6}$, A Gardemann ${ }^{1}$, B Isermann ${ }^{5}$ and A Goette ${ }^{1,7}$ \\ ${ }^{1}$ Institute of Clinical Chemistry and Pathobiochemistry, Department of Pathobiochemistry, Otto-von-Guericke University Magdeburg, \\ Magdeburg 39120, Germany; ${ }^{2}$ Medical Department I, Division of Rheumatology, Charitá University Medicine Berlin, Berlin 12203, \\ Germany; ${ }^{3}$ Institute of Medical Biochemistry and Molecular Biology, University Medicine Greifswald, Greifswald 17479, Germany; \\ ${ }^{4}$ Department of Cardiology, Otto-von-Guericke University Magdeburg, Magdeburg 39120, Germany; ${ }^{5}$ Department of Clinical Chemistry, \\ Institute of Clinical Chemistry and Pathobiochemistry, Otto-von-Guericke University Magdeburg, Magdeburg 39120, Germany; \\ ${ }^{6}$ Department of Cardiothoracic Surgery, Otto-von-Guericke University Magdeburg, Magdeburg 39120, Germany; ${ }^{7}$ St. Vincenz-Hospital, \\ Paderborn 33098, Germany \\ Corresponding author: Alicja Bukowska. Email: alicja.bukowska@med.ovgu.de
}

Impact statement

The present study demonstrates that estrogen affects the human atrial myocardium and mediates protective actions through estrogen receptors-(ER) dependent signaling. Estrogen substantially modulates the local RAS via downregulation of ACE and simultaneous upregulation of ACE2, AT2R and MAS expression levels. This is indicative of a shift of the classical RAS/ACE axis to the alternative, protective RAS/ACE2 axis. In support of this view, estrogen attenuated the expression of RAS-associated downstream effectors, LOX-1, and ICAM-1. A specific antagonist of $E R \alpha$ reversed the anti-inflammatory and anti-oxidative effects of estrogen in paced and nonpaced atrial tissue slices. In summary, our data demonstrate the existence of protective effects of estrogen in atrial tissue from elderly men which are at least in part, mediated by the regulation of local RAS homeostasis.

\begin{abstract}
Data from animal experiments and clinical investigations suggest that components of the renin-angiotensin system are markedly affected by sex hormones. However, whether estrogen affects human atrial myocardium has not been investigated yet. In this study, we determined the effects of estrogen on key components of atrial renin-angiotensin system: angiotensin-converting enzyme, responsible for generation of angiotensin II and angiotensin-converting enzyme 2, counteracting majority of Angll effects, and different renin-angiotensin system receptors, AT1R, AT2R, and MAS. First, the expression levels of estrogen receptors $m R N A$ were determined in right atrial appendages obtained from patients undergoing heart surgery. The amounts of estrogen receptor $\alpha$ and estrogen receptor $\beta$ mRNA were similar between women $(n=14)$ and men $(n=10)$. Atrial tissue slices $(350 \mu \mathrm{m})$ were prepared from male donors which were exposed to estrogen (1-100 nM; $n=21$ ) or stimulated at $4 \mathrm{~Hz}$ for $24 \mathrm{~h}$ in the presence or absence of $100 \mathrm{nM}$ estrogen $(n=16)$, respectively. The administration of estrogen did not change mRNA levels of estrogen receptors, but activated MAP kinases, Erk1/2. Furthermore, estrogen increased the amounts of angiotensin-converting enzyme 2-mRNA $(1.89 \pm 0.23 ; P<0.05)$ but reduced that of angiotensin-converting enzyme-mRNA $(0.78 \pm 0.07, P<0.05)$. In addition, the transcript levels of AT2R and MAS were upregulated by estrogen. Pacing of tissue slices sig-
\end{abstract}

nificantly increased the angiotensin-converting enzyme/angiotensin-converting enzyme 2 ratio at both the mRNA and protein level. During pacing, administration of estrogen substantially lowered the angiotensin-converting enzyme/angiotensin-converting enzyme 2 ratio at the transcript $(0.92 \pm 0.21 \mathrm{vs} .2 .12 \pm 0.27$ at $4 \mathrm{~Hz})$ and protein level $(0.94 \pm 0.20 \mathrm{vs} .2 .14 \pm 0.3$ at $4 \mathrm{~Hz})$. Moreover, estrogen elicited anti-inflammatory and anti-oxidative effects on renin-angiotensin system-associated downstream effectors such as pro-oxidative LOX-1 and pro-inflammatory ICAM-1. An antagonist of estrogen receptor $\alpha$ reversed these anti-inflammatory and anti-oxidative effects of estrogen significantly. Overall, our results demonstrated that estrogen modifies the local renin-angiotensin system homeostasis and achieves protective effects in atrial myocardium from elderly men.

Keywords: Human atrial myocardium, estrogen, estrogen receptors, renin-angiotensin-system, angiotensin-converting enzyme 2, atrial remodeling

Experimental Biology and Medicine 2017; 242: 1412-1423. DOI: 10.1177/1535370217718808 


\section{Introduction}

Estrogen is a powerful steroid involved in numerous biological processes in a variety of tissues including heart myocardium. Upon binding to the estrogen receptors (ERs), it mediates diverse biological effects by nuclear and/or nonnuclear mode of actions. ${ }^{1}$ The rapid, non-nuclear response to estrogen involves membrane-associated ERs and activates kinase cascades including phosphatidylinositol-3 kinase (PI3K), protein kinase B (Akt), and an extracellular signal-regulated kinase (ERK). The nuclear response is much slower, as it requires the ER-estrogen complex to translocate into the nucleus where it binds to estrogen response elements to activate or repress target gene transcription. ERs can also be recruited to chromatin through interaction with other transcription factors, such as SP1, nuclear factor- $\kappa \mathrm{B}(\mathrm{NF}-\kappa \mathrm{B})$, and $\mathrm{AP}-1 .{ }^{2}$

Cardiovascular studies have demonstrated that the rapid, non-nuclear signaling pathway is involved in the estrogen-mediated protection against diseases. This signaling has been extensively studied in endothelial and vascular smooth muscle cells, where complexes of estrogen and ERs led to the rapid activation of endothelial nitric oxide synthase (eNOS), and production of nitric oxide (NO). ${ }^{3,4}$ NO has various beneficial actions, including vascular relaxation, the attenuation of cell growth and migration, the inhibition of platelet activation, thrombus formation, and leukocyte-endothelial cell adhesion. It has been shown that the myocardium is also a target tissue for estrogen. Cardiac myocytes contain functional ERs, ER $\alpha$ and ER $\beta$. Exposure of neonatal and adult cardiac myocytes cultures to estrogen caused translocation of the ER into the nucleus and increased expression of eNOS. ${ }^{5,6}$ The protection in cardiomyocytes was also associated with the activation of ERK $1 / 2 .^{7}$ In line with this, it was demonstrated that estrogen reduces cardiomyocyte apoptosis by rapid activation of Akt in myocardial injury. ${ }^{8}$ Furthermore, estrogen reduces pathologic hypertrophy by an ER-dependent mechanism that leads to increased degradation of calcineurin. ${ }^{9}$ Moreover, estrogen has been implicated in the regulation of numerous specific cardiac genes. ${ }^{5}$

Data from experimental animals and clinical investigations suggest that components of the circulating as well as tissue renin-angiotensin systems (RAS) are markedly affected by gender. ${ }^{10,11}$ Evidence clearly demonstrates that premenopausal women, as compared to aged-matched men, are protected from renal and cardiovascular disease. ${ }^{12}$ With growing age, this cardiovascular protection is lost in women. The RAS is appreciated as key to the pathophysiology of various disease states and could be mechanistically implicated in initiation and perpetuation of atrial arrhythmia as well as providing the link to other mechanisms promoting the prothrombotic state in atrial fibrillation (AF). In fact, few hours of rapid atrial pacing are sufficient to elevate plasma levels of angiotensin II (AngII) suggesting a very early involvement in the pathology of AF. ${ }^{13-16}$ The elevated levels of AngII, which result from an increased expression/ activity of angiotensin-converting enzyme (ACE) ${ }^{17}$ mediate tissue remodeling and exert direct pro-arrhythmogenic effects in human atrial tissue. There is a growing interest in the regulation of the tissue RAS by sex hormones. However, whether estrogen influences RAS in human atrial myocardium is unknown. The purpose of this study is to investigate effects of $17 \beta$-estradiol (E2, estrogen) on two critical components: (I) cardiac ACE, responsible for generation of AngII and (II) angiotensin-converting enzyme 2 (ACE2), counteracting majority of AngII effects. Moreover, we address in this study the ability of E2 to influence the expression of pro-inflammatory and pro-oxidative molecules, which participate in the atrial prothrombotic remodeling.

\section{Materials and methods Heart tissue samples}

Right atrial appendages (RAAs) were obtained from 86 patients undergoing heart surgery for coronary artery bypass graft or mitral/aortic valve replacement. None of the patients had a history of documented sustained arrhythmias. Treatments were usually stopped $24 \mathrm{~h}$ before surgery. The study conforms to the Declaration of Helsinki and was approved by the local Ethics Committee. All patients gave written informed consent to participate in the study. First, the status of ERs was determined in samples from women $(n=14)$ and men $(n=10)$. Second, the concentration of E2 was measured in atrial tissue from women $(n=13)$ and men $(n=12)$. Then, atrial tissue from male donors was used to prepare atrial tissue slices and investigates the effects of E2 $(n=37)$. The distribution of samples and clinical characteristics of patients are shown in Tables 1 and 2.

\section{Culturing tissue slices and in vitro pacing}

The atrial tissue slices were prepared in cold, oxygenated $\left(\begin{array}{lll}95 \% & \mathrm{O}_{2} / 5 \% & \mathrm{CO}_{2}\end{array}\right)$ Tyrode buffer using a vibratome (VT1200S; Leica Microsystems, Wetzlar, Germany). The $350 \mu \mathrm{m}$ slices were placed on top of the membrane of tissue culture inserts $(0.4 \mu \mathrm{m}$ Merck Millipore, Darmstadt, Germany) and cultured in a petri dish, which was filled with DMEM medium (Life Technologies $\mathrm{GmbH}$, Darmstadt, Germany) for up to $24 \mathrm{~h}$ in an incubator $(21 \%$ $\mathrm{O}_{2}, 5 \% \mathrm{CO}_{2}, 37^{\circ} \mathrm{C}$ ). For stimulation in an electrical field, a pair of custom-built carbon electrodes was submersed at the opposite ends of a petri dish and connected to a stimulation unit (GRASS Stimulator) as previously described. ${ }^{18}$ Pacing of the tissue slices was performed within the serum-free DMEM medium up to $24 \mathrm{~h}$ at $37^{\circ} \mathrm{C}$ at rates of 0.6 and $4.0 \mathrm{~Hz}(10 \mathrm{~V} / \mathrm{cm}, 5 \mathrm{~ms}$ bipolar pulse). Atrial tissue slices were cultured $(n=21)$, or stimulated in the electrical field $(n=16)$ in the presence of E2 (17 $\beta$-estradiol, Sigma, Germany). In some experiments, tissue slices were preincubated for $1 \mathrm{~h}$ with $10 \mu \mathrm{M}$ of MPP (Sigma), an ER $\alpha$ antagonist, or with $10 \mu \mathrm{M}$ of PHTPP (Sigma), an ER $\beta$ antagonist. The distribution of samples and clinical characteristics of patients are shown in Table 2.

The viability of cultured human atrial tissue slices was confirmed using an established viability staining technique (CellTracker Green CMFDA, Invitrogen, Karlsruhe, Germany). ${ }^{19}$ The living slices were incubated for $2 \mathrm{~h}$ with the final concentration of $5 \mu \mathrm{M}$ dye in serum-free medium 
Table 1 The clinical characteristic of patients

\begin{tabular}{|c|c|c|c|c|c|c|}
\hline & \multicolumn{3}{|c|}{$E_{2}$ receptor status } & \multicolumn{3}{|l|}{ E2 level } \\
\hline & women & men & $P$ & women & men & $P$ \\
\hline Patients & $n=14$ & $n=10$ & & $n=13$ & $n=12$ & \\
\hline Age & $71 \pm 7$ & $69 \pm 5$ & ns & $70 \pm 11$ & $69 \pm 10$ & ns \\
\hline Heart valve disease: & $9(64)$ & $5(50)$ & ns & $6(46)$ & 7 (58) & ns \\
\hline Mitral insufficiency & $4(29)$ & $2(20)$ & ns & $3(23)$ & $7(58)$ & ns \\
\hline Aortic stenosis & $4(29)$ & $1(10)$ & ns & $3(23)$ & $2(17)$ & ns \\
\hline Aortic insufficiency & $6(43)$ & $4(40)$ & ns & $2(15)$ & $2(17)$ & ns \\
\hline Myocardial infarction & $4(29)$ & $4(40)$ & ns & $6(46)$ & $4(33)$ & ns \\
\hline Hypertension & $11(79)$ & $9(90)$ & ns & $12(92)$ & $11(92)$ & ns \\
\hline Coronary heart disease & $\begin{array}{l}10(71) \\
2.4 \pm 0.9\end{array}$ & $\begin{array}{c}8(80) \\
2.7 \pm 0.5\end{array}$ & ns & $\begin{array}{c}11(85) \\
2.4 \pm 0.7\end{array}$ & $\begin{array}{c}11(92) \\
2.6 \pm 0.7\end{array}$ & ns \\
\hline Diabetes mellitus & $7(50)$ & $4(40)$ & ns & 7 (54) & 7 (58) & ns \\
\hline Hyperlipoproteinemia & $9(64)$ & $6(60)$ & ns & $10(77)$ & $9(75)$ & ns \\
\hline \multicolumn{7}{|l|}{ Therapy: } \\
\hline Beta blockers & $12(86)$ & $5(50)$ & ns & $10(77)$ & $6(50)$ & ns \\
\hline Ca-Antagonists & $4(29)$ & $4(40)$ & ns & $5(38)$ & $4(33)$ & ns \\
\hline Statins & $8(57)$ & $5(50)$ & ns & $7(54)$ & $10(83)$ & ns \\
\hline ACE-Inhibitor/ARB & $8(57)$ & $8(80)$ & ns & $6(46)$ & $6(50)$ & ns \\
\hline
\end{tabular}

Note: Values are mean \pm SD or $n(\%)$; percentages are calculated according to available data set. ACE: angiotensin-converting enzyme; ARB: angiotensin-receptor inhibitor; ns: non-significant results

Table 2 The clinical characteristic of patients (experimental part)

\begin{tabular}{|c|c|c|c|c|c|}
\hline & \multicolumn{5}{|c|}{ Atrial slices from male patients } \\
\hline & \multicolumn{3}{|c|}{ Resting conditions } & \multicolumn{2}{|l|}{ Pacing } \\
\hline & $\begin{array}{l}\text { LDH/viability } \\
\text { test }\end{array}$ & RNA/WB & $\begin{array}{l}\text { RNA/WB + ER } \\
\text { antagonists }\end{array}$ & RNA/WB & $\begin{array}{l}\text { RNA/WB + ER } \\
\text { antagonists }\end{array}$ \\
\hline Patients & $n=4$ & $n=12$ & $n=5$ & $n=12$ & $n=4$ \\
\hline Age & $70 \pm 9$ & $60 \pm 6$ & $70 \pm 5$ & $64 \pm 8$ & $60 \pm 14$ \\
\hline Heart valve disease: & $2(50)$ & $5(42)$ & $4(80)$ & $6(50)$ & $3(75)$ \\
\hline Mitral insufficiency & $0(0)$ & $3(25)$ & $1(20)$ & $3(25)$ & $3(75)$ \\
\hline Aortic stenosis & $2(50)$ & $2(16)$ & $3(60)$ & $4(33)$ & $0(0)$ \\
\hline Aortic insufficiency & $1(25)$ & $2(16)$ & $0(0)$ & $3(25)$ & $1(25)$ \\
\hline Myocardial infarction & $1(25)$ & $5(42)$ & $1(20)$ & $4(33)$ & $2(50)$ \\
\hline Hypertension & $4(100)$ & $11(92)$ & $5(100)$ & $10(83)$ & $4(100)$ \\
\hline Coronary heart disease & $\begin{array}{l}3(75) \\
2.3 \pm 0.6\end{array}$ & $\begin{array}{l}8(67) \\
2.6 \pm 0.7\end{array}$ & $\begin{array}{l}5(100) \\
3.0 \pm 0.0\end{array}$ & $\begin{array}{l}9(75) \\
2.8 \pm 0.4\end{array}$ & $\begin{array}{l}4(100) \\
2.7 \pm 0.5\end{array}$ \\
\hline Diabetes mellitus & $1(25)$ & $4(33)$ & $1(20)$ & $6(50)$ & $0(0)$ \\
\hline Hyperlipoproteinemia & $3(75)$ & $9(75)$ & $5(100)$ & $6(50)$ & $3(75)$ \\
\hline \multicolumn{6}{|l|}{ Therapy: } \\
\hline Beta blockers & $3(75)$ & $10(83)$ & $3(60)$ & $9(75)$ & $3(75)$ \\
\hline Ca-Antagonists & $0(0)$ & $4(33)$ & $1(20)$ & $4(33)$ & $0(0)$ \\
\hline Statins & $3(75)$ & $5(42)$ & $5(100)$ & $10(83)$ & $4(100)$ \\
\hline ACE-Inhibitor/ARB & $2(50)$ & $9(75)$ & $4(80)$ & $7(58)$ & $2(50)$ \\
\hline
\end{tabular}

Note: Values are mean \pm SD or $n(\%)$; percentages are calculated according to available data set.

ACE: angiotensin-converting enzyme; ARB: angiotensin-receptor inhibitor; ns: non-significant results.

and imaged as stitched mosaic with a fluorescent microscope (Axiovert $200 \mathrm{~m}$; Carl Zeiss Microscopy GmbH, Jena, Germany) using an excitation wavelength filter of $480 / 40 \mathrm{~nm}$, a diachroic filter $505 \mathrm{~nm}$ long pass and emission wavelength between filter of 535/50 nm. The cellular integrity of tissue slices was assessed using lactate dehydrogenase (LDH) assay (Roche Diagnostics, Mannheim, Germany). The effect of different concentrations of E2 on the enzyme 
release from slices into culture medium was monitored during $24 \mathrm{~h}$. To determine the total LDH content, atrial slices were collected, homogenized in $1 \mathrm{ml}$ medium with $0.5 \%$ triton $\mathrm{X}-100$. The loss of the enzyme within the slices was measured after $24 \mathrm{~h}$ of incubation. The test was performed according to the manufacturer's instructions.

\section{Quantitative RT-qPCR}

Total RNA was isolated from atrial tissue slices using Nucleo SpinRNAII (Macherey-Nagel, Germany) in combination with TRIzol/chloroform extraction (Invitrogen, Germany). Reverse transcription was carried out with $1 \mu \mathrm{g}$ of each RNA using random primer by means of Fermentas kit according to the manufacture's protocol (Fermentas, Germany). Quantitative PCR was performed using the iCycler (BioRad, Munich, Germany). A $25-\mu 1$ reaction mixture consisted of $1 \times$ SensiMix (Quantace, Bioline, UK), $1 \mu \mathrm{l}$ cDNA, and $0.3 \mu \mathrm{M}$ of the specific primers (Table 3). Initial denaturation at $95^{\circ} \mathrm{C}$ for $10 \mathrm{~min}$ was followed by 40 cycles with denaturation at $95^{\circ} \mathrm{C}$ for $10 \mathrm{~s}$, annealing at $60-62^{\circ} \mathrm{C}$ for $20 \mathrm{~s}$, and elongation at $72^{\circ} \mathrm{C}$ for $20 \mathrm{~s}$. Before starting quantification of mRNA amounts by RT-qPCRs, validation experiments were performed with respect to specificity, efficiency, and background signal in negative controls. Amplification specificity of PCR products was confirmed by melting curve analysis and agarose gel electrophoresis. Amplification efficiencies were calculated from the results of the dilution series of human atrial cDNA and calculated according to the equation $\mathrm{E}$ (Efficiency) in $\%=\left\{\left[10^{(-1 / \text { slope })}\right]-1\right\} \times 100$. The efficiencies between 90 and $110 \%$ were considered as to be of sufficient quality and used for the study (Table 3). Target gene expression was normalized to the reference gene, GAPDH, and calculated using the $\Delta \Delta \mathrm{Ct}$ method. ${ }^{20}$

\section{Western blot analysis}

Atrial tissue slices were homogenized in modified RIPA buffer, which contained $50 \mathrm{mM}$ Tris- $\mathrm{HCl}$ ( $\mathrm{pH} 7.5), 100 \mathrm{mM}$ $\mathrm{NaCl}, 5 \mathrm{mM}$ EDTA, $0.5 \%$ Triton X-100, 10\% glycerol, $10 \mathrm{mM}$ $\mathrm{K}_{2} \mathrm{HPO}_{4}, 0.5 \% \mathrm{NP}-40,1 \mathrm{mM}$ PMSF, $1 \mathrm{mM}$ sodium vanadate, $0.5 \%$ deoxycholate, $20 \mathrm{mM} \mathrm{NaF}, 20 \mathrm{mM}$ glycerol-2-phosphate, and a protease inhibitor cocktail (all from Sigma, Heidelberg, Germany). Tissue homogenates were centrifuged at $15,000 \times g$ for $30 \mathrm{~min}$ and the resulting supernatant (total tissue homogenate) was stored at $-20^{\circ} \mathrm{C}$ for analysis. Protein samples of $20 \mu \mathrm{g}$ each were separated by SDS-PAGE and transferred to PVDF membranes. The membranes were incubated with primary antibody against phospho- $44 / 42$ ERK (1:1000; Cell Signaling, MA, USA), 44/42ERK (1:1000, Cell Signaling, MA, USA), LOX-1 (1:1000, Santa Cruz, USA), ICAM-1 (1:500, Santa Cruz, USA), GAPDH (1:5000, Santa Cruz, USA) followed by incubation with an appropriate horseradish peroxidase-conjugated secondary antibody and detection using enhanced chemiluminescence (Pierce, Rockford, USA). The protein expression was quantified using AlphaEaseFC software (AlphaImager System,

Table 3 Primer used for quantitative RT-PCR

\begin{tabular}{|c|c|c|c|c|}
\hline Gene & $\mathbf{T}\left({ }^{\circ} \mathbf{C}\right)$ & $E^{\star}(\%)$ & Size (bp) & Sequences \\
\hline ACE & 60 & 97 & 262 & $\begin{array}{l}\text { US: 5'- CTCAAGTACTTCCAGCCAGTC- 3' } \\
\text { DS: 5'- GCAGAATCTTGCTGGTCTCTG- 3' }\end{array}$ \\
\hline ACE2 & 60 & 95 & 372 & $\begin{array}{l}\text { US: 5'- CTCCTTCTCAGCCTTGTTGC- 3' } \\
\text { DS: 5'- TCCAGTACTGTAGATGGTGC- 3' }\end{array}$ \\
\hline AT1R & 58 & 94 & 416 & $\begin{array}{l}\text { US: 5'- GACGCACAATGCTTGTAGCCA- 3' } \\
\text { DS: 5'- CTGCAATTCTACAGTCACGTATG- 3' }\end{array}$ \\
\hline AT2R & 60 & 104 & 214 & $\begin{array}{l}\text { US: 5'- GTAAATCAGCCACAGCGAGG- 3' } \\
\text { DS: 5'- GGGCTTGTGAACATCTCTGG- 3' }\end{array}$ \\
\hline eNOS & 62 & 90 & 559 & $\begin{array}{l}\text { US: 5'- GAGAATGGAGAGAAGCTTTGC- } 3^{\prime} \\
\text { DS: 5'- GGATTGTAGCCTGGAACATC - 3' }\end{array}$ \\
\hline $\mathrm{ER} \alpha$ & 60 & 96 & 401 & $\begin{array}{l}\text { US: 5'- GTGCCTGGCTAGAGATCCTG- 3' } \\
\text { DS: 5'- GATGTGGGAGAGGATGAGGA- 3' }\end{array}$ \\
\hline ER $\beta$ & 62 & 105 & 245 & $\begin{array}{l}\text { US: 5'- TCAGGCATGCGAGTAACAAG- 3' } \\
\text { DS: 5'- TTCAGCCTGTGACCTCTGTG- 3' }\end{array}$ \\
\hline GAPDH & $58-62$ & 92 & 600 & $\begin{array}{l}\text { US: 5'- TCCAAAATCAAGTGGGGCGATGCT- 3' } \\
\text { DS: 5'- ACCACCTGGTGCTCAGTGTGACCC- 3' }\end{array}$ \\
\hline ICAM-1 & 62 & 96 & 437 & $\begin{array}{l}\text { US: 5'- AGTCAGTGTGACCGCAGAGG- 3' } \\
\text { DS: 5'- CCTGGCACATTGGAGTCTGC- 3' }\end{array}$ \\
\hline MAS & 60 & 90 & 407 & $\begin{array}{l}\text { US: 5'- CAATGCCGACTGGTACTTG- 3' } \\
\text { DS: 5'- ACATCTCAACTGGCAGGAAC- 3' }\end{array}$ \\
\hline LOX-1 & 60 & 95 & 458 & $\begin{array}{l}\text { US: 5'- ACAGATCTCAGCCCGGCAACAAGCA- 3' } \\
\text { DS: 5'- GGGAGACAGCGCCTCGGACTCTAAAT- 3' }\end{array}$ \\
\hline \multicolumn{5}{|c|}{ E: Efficiency in $\%=\left\{\left[10^{(-1 / \text { slope })}\right]-1\right\} \times 100$} \\
\hline
\end{tabular}

ACE: angiotensin-converting enzyme; ACE2: angiotensin-converting enzyme 2; AT1R: AT1 receptor; AT2R: AT2 receptor; eNOS: endothelial nitric oxide synthase; ER $\alpha$ : estrogen receptor $\alpha$; ER $\beta$ : estrogen receptor $\beta$; ICAM-1: intercellular adhesion molecule; LOX-1: oxidized low density lipoprotein receptor. 
Alpha Innotech, CA, USA). Target protein bands were normalized to GAPDH (ratio of target protein and GAPDH) in the same sample and then compared to the untreated control to calculate the fold-change.

\section{Determination of estrogens in atrial tissue}

Frozen samples (50-190 g) were homogenized in 70\% ethanol using an Ultra-Turrax apparatus. The homogenates were centrifuged at $9000 \mathrm{~g}$ at $4^{\circ} \mathrm{C}$ for $30 \mathrm{~min}$. The resulted supernatants were evaporated to dryness with nitrogen and dissolved in PBS. A chemiluminescence immunoassay (IMMULITE $^{\circledR} 2000$ Estradiol, Siemens) method was used for the determination of E2 level in atrial tissue. The values were expressed in $\mathrm{mol} / \mathrm{g}$ tissue.

\section{Statistical analysis}

All values are expressed as mean \pm SEM if not indicated otherwise. Statistical analyses were performed using Origin 8.5 (OriginLab Corporation, USA). An assessment of the normality of data distribution was performed with Shapiro-Wilk test. ANOVA-tests followed by post hoc Tukey test were used to analyze the data. A $P$ value of $<0.05$ was considered to be statistically significant.

\section{Results}

\section{Expression of the ERs in human atrial myocardium}

First of all, we investigated the ERs status in the RAAs from men (age 69 \pm 5 ) and women (age 72 \pm 8 ) (Table 1). The PCR analyses revealed that the atrial tissue expresses both receptors: ER $\alpha$ and ER $\beta$. The gender-dependent comparison of the expression of ER subtypes showed no significant differences between men and women (Figure 1). Then, we determined levels of E2 in atrial myocardium from elderly men and women. As shown in Figure 1(b), tissue E2 concentration from women was slightly higher than in men ( $3.47 \pm 0.47$ vs. $2.93 \pm 0.31 \mathrm{pmol} / \mathrm{g}$ tissue, $P=\mathrm{ns})$.

\section{Viability of human atrial tissue slices}

To study the impact of E2 on human atrial tissue, slices from RAAs were prepared and cultured up to $24 \mathrm{~h}$. The viability of the ex vivo cultured human slices is demonstrated in Figure 2(a). Moreover, the cellular integrity of atrial slices was monitored by measurements of lactate dehydrogenase (LDH) under different study conditions. As shown in Figure 2(b), the administration of different concentration of E2 did not influence viability of slices. The LDH leakage was determined as a percentage of the total LDH present in the slices after $24 \mathrm{~h}$ of culturing experiments or stimulation in the electrical field as shown in Figure 2(c).

\section{Effects of $17 \beta$-estradiol on the expression of RAS components in human atrial myocardium}

To elucidate whether E2 influences the RAS, we analyzed the expression of the angiotensin converting enzymes, ACE and ACE2, and RAS receptors: AT1R and AT2R (angiotensin receptor type 1 and 2), MAS (Ang-(1-7) receptor). The mRNA analysis revealed an opposite regulation of ACE

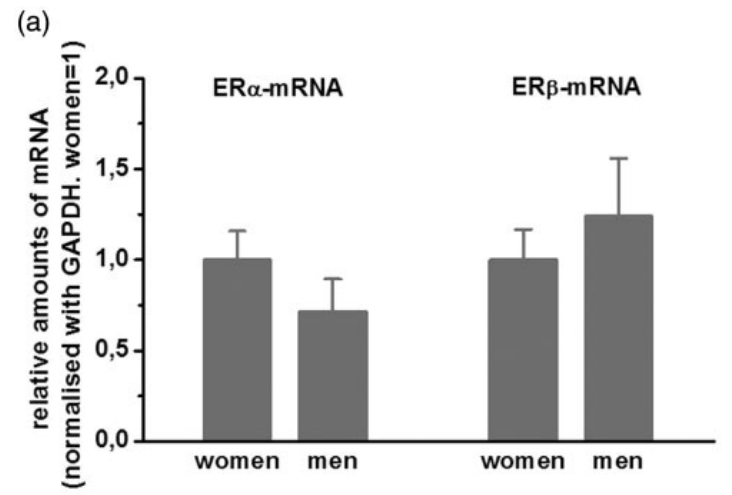

(b)

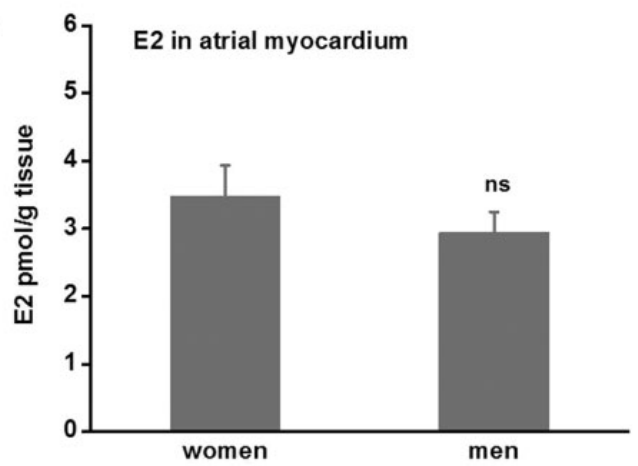

Figure 1 Expression of estrogen receptors (ER) and estrogen in the human right atrial myocardium. (a) ER $\alpha$ - and ER $\beta$-mRNA were analyzed using RT-qPCR in the atrial myocardium of women and men. The difference in the expression was not significant. Results are expressed as means \pm SEM; ER $\alpha$ - and ER $\beta-m R N A$ for women were set as 1 respectively. (b) Comparison of E2 concentrations in right atrial tissue from elderly women and men

and ACE2 by E2 at resting conditions (Figure 3(a)). Whereas E2 significantly suppressed the expression of ACE $\quad(100 \mathrm{nM}$ E2: $0.78 \pm 0.07$ vs. $1.0 \pm 0.08 ; \quad P<0.05$; $n=15$ ), the expression of ACE2 was significantly elevated (100 nM E2: $1.89 \pm 0.23$ vs. $1.0 \pm 0.14 ; P<0.05, n=15)$ (Figure 3(a)). Western blot analyses confirmed this E2 effect on ACE (100 nM E2: $61 \pm 8 \%$ vs. $100 \pm 8 \%$; $P<0.05$; $n=11)$ and ACE2 (100 nM E2: $200 \pm 23 \%$ vs. $100 \pm 16 \%$; $P<0.05 ; n=11)$. We also performed additional experiments to determine whether ERs are involved in the E2-induced effects in atrial slices. Thus, the specific antagonists of ER $\alpha$ (MPP) and ER $\beta$ (PHTTP) were added into culture medium with slices exposed to E2. As revealed our analysis at the mRNA and protein level, the antagonist of ER $\alpha$ prevented the E2-mediated increase in the ACE2 expression significantly (mRNA: $1.21 \pm 0.14$; protein: $111 \pm 14 \%$, $P<0.05 ; n=5)$. The antagonist of ER $\beta$ did not influence the effects of E2 on ACE2. Indistinct results were achieved in regard to the expression of ACE. Neither $E R \alpha-$ nor ER $\beta$-antagonist could restore completely the reduced levels of ACE-mRNA or ACE-protein (Figure 3(a), (b), and (e)).

The AT1R mRNA (100 nM E2: $0.98 \pm 0.05$ vs. $1.0 \pm 0.16$, $n=15)$ and protein (100 nM E2: $101 \pm 7 \%$, vs. $100 \pm 12 \%$ control, $n=5$ ) were not affected by E2 (Figure 3(c) and (f)). However, the transcriptional levels of AT2R and MAS were upregulated in the presence of E2 (Figure 3(c) and 
(a)

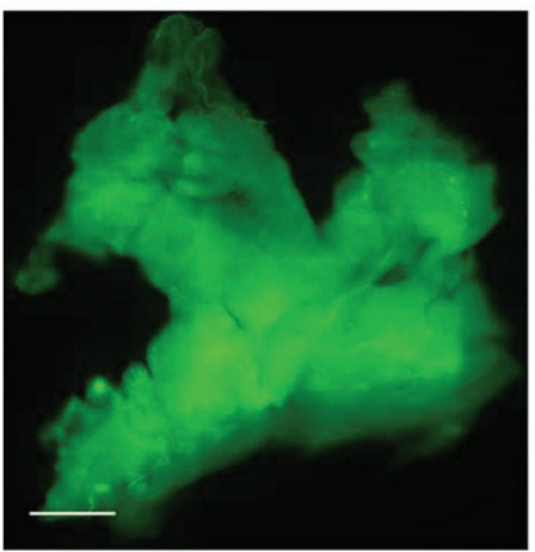

(b)
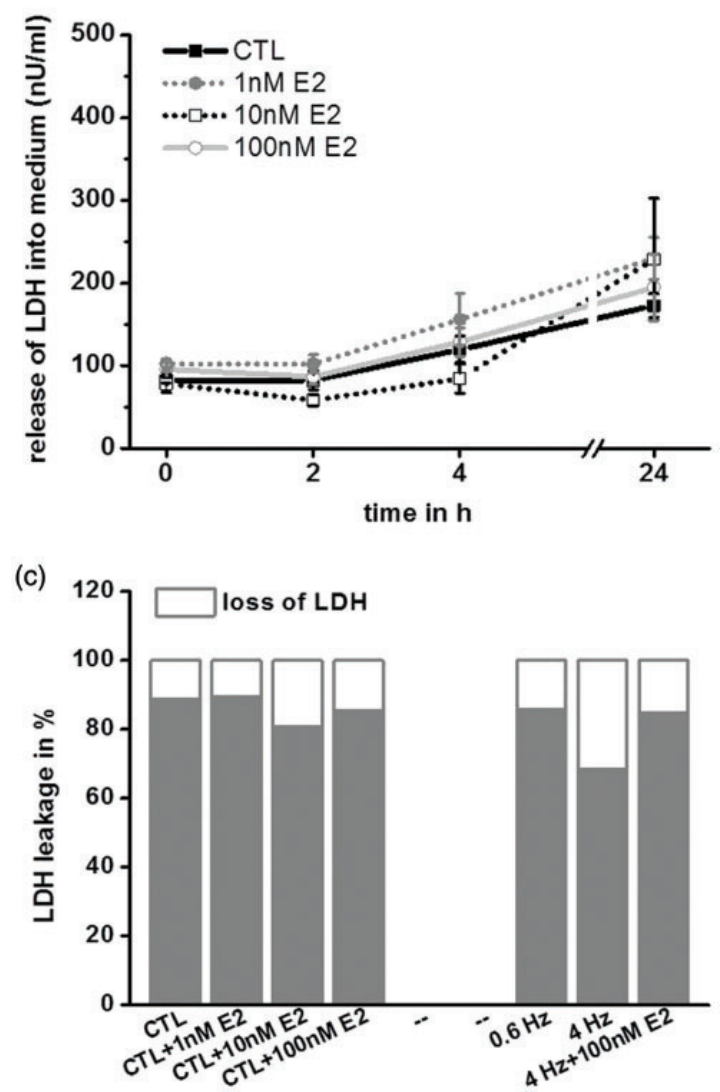

Figure 2 Viability of tissue slices. (a) Representative stitched image of $350 \mu \mathrm{m}$ thick human slices from the right appendages stained with cell tracker green after $24 \mathrm{~h}$ of culturing. Scale bar: $1000 \mu \mathrm{m}$. (b) The measurements of release of lactate dehydrogenase (LDH) revealed that administration of different concentration of E2 did not influence viability of slices. (c) The integrity of atrial slices was expressed by LDH leakage during culturing or stimulation in the electrical field. The LDH leakage was determined as a percentage of the total LDH present in the slices present in the slices after $24 \mathrm{~h}$ of culturing experiments. Results are expressed as means \pm SEM at least of four experiments. (A color version of this figure is available in the online journal.)

(f)). The administration of the ER $\alpha$-antagonist, MPP, prevented the E2-mediated increase in the AT2R-mRNA $(0.65 \pm 0.12$ vs. $2.0 \pm 0.27 ; n=5 ; P<0.05)$ and the MASmRNA $(0.83 \pm 0.27$ vs. $1.73 \pm 0.26 ; n=5 ; P<0.05)$. The administration of the ER $\beta$-antagonist, PHTPP, did not affect the E2-induced effects on the ACE2 or MAS expressions (Figure 3(c)). The increase in AT2R protein by E2 was confirmed at the protein level $(166 \% \pm 7 \%$, vs. $100 \pm 11$ control, $n=5, P<0.05$ ) (Figure 3(f)). However, the effects of ERs antagonists on AT2R protein did not reach statistical significances.

To mimic the condition of $\mathrm{AF}$, atrial tissue slices were stimulated in the electrical field at a frequency of $4 \mathrm{~Hz}$. As demonstrated in Figure $3(\mathrm{~g})$, rapid pacing enhanced the expression level of ACE but lowered that of ACE2. To better illustrate the relation of the two counteracting enzymes at the transcriptional and at the protein level, ACE/ACE2 ratios were considered (Figure 3(d)). Even under conditions of rapid pacing, E2 was capable of exhibiting its regulatory properties and provoked a down regulation of ACE expression and up regulation of ACE2expression. As illustrated in Figure 3(d), E2 lowered significantly the ratio of ACE/ACE2 at the transcriptional $(0.92 \pm 0.21$ vs. $2.1 \pm 0.22$ at $4 \mathrm{~Hz} ; n=10 ; P<0.01)$ and protein level $(0.94 \pm 0.16$ vs. $2.1 \pm 0.3$ at $4 \mathrm{~Hz} ; n=11 ; P<0.01)$. The administration of ER $\alpha$-antagonist restored the effects of E2 partially.

\section{Activation of ERK kinases and eNOS in atrial tissue}

Tissue slices were exposed to different concentrations of E2 for up to $24 \mathrm{~h}$ and the phosphorylation state of ERK kinases was analyzed. As shown in Figure 4(a), E2 provoked an activation of ERK $(100 \mathrm{nM} \mathrm{E2:} 197 \pm 26 \%, 10 \mathrm{nM} \mathrm{E2:}$ $183 \pm 34 \%$ vs. $100 \pm 22 \% ; P<0.05, n=11)$. The administration of the specific antagonist of ER $\alpha, \mathrm{MPP}$, prevented the phosphorylation of ERK significantly $(113 \pm 15 \%, P<0.05$; $n=5$ ) (Figure 4(a) and (b)).

The PCR analysis revealed that E2 has no influence on the ER $\alpha-m R N A$ amount $(1 \mathrm{nM} \mathrm{E2:} 1.1 \pm 0.3$; $100 \mathrm{nM} \mathrm{E2:}$ $0.90 \pm 0.09 ; n=9)$, and on the ER $\beta$-mRNA amount $(1 \mathrm{nM}$ E2: $1.2 \pm 0.05 ; 100 \mathrm{nM}$ E2: $0.82 \pm 0.22 ; n=6$ ) (Figure $4(\mathrm{c})$ ). However, exposure to E2 increased the expression of eNOS $(1 \mathrm{nM} \quad$ E2: $1.76 \pm 0.32, \quad P<0.05 ; \quad 100 \mathrm{nM} \quad$ E2: $1.64 \pm 0.33$, vs. $1.0 \pm 0.22 ; n=10$ ) (Figure $4(\mathrm{c})$ ).

\section{$17 \beta$-oestradiol diminished the atrial expression of NF- $\mathrm{kB}$ target genes}

In order to investigate whether E2 affects the expression of $\mathrm{NF}-\kappa \mathrm{B}$ target genes in the atrial myocardium, the expression of oxidized receptor for low density lipoprotein (LOX-1) and intercellular adhesion molecule (ICAM-1) was determined at the mRNA and protein level. E2 at higher concentration provoked a significant decrease of the LOX-1 mRNA $(100 \mathrm{nM}$ E2: $0.67 \pm 0.05$ vs. $1.0 \pm 0.16$; $P<0.05, \quad n=15) \quad$ (Figure 5(a)), and ICAM-1-mRNA (100 nM E2: $0.63 \pm 0.09$ vs. $1.0 \pm 0.2, \quad P<0.05 ; n=15$ ) (Figure 5(a)). These results were then confirmed at the protein level. The Western blot analysis demonstrated that E2 reduces the LOX-1 protein $(100 \mathrm{nM} \mathrm{E2:} 56 \pm 7 \%$ vs. $100 \pm 14 \% ; P<0.01, n=11)$ and ICAM-1 protein significantly (100 nM E2: $56 \pm 7 \%$ vs. $100 \pm 17 \% ; P<0.01, n=11)$ (Figure 5). In additional experiments, we determined effects of the specific antagonists of ER $\alpha$ (MPP) and ER $\beta$ (PHTTP) on the E2-dependent downregulation of LOX-1 and ICAM1. At the mRNA and protein level, an antagonist of ER $\alpha$ 
(a)

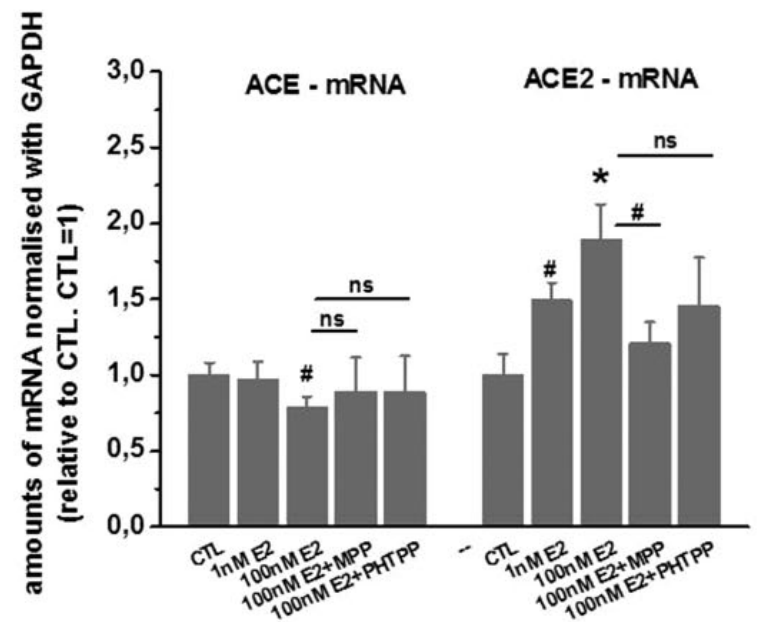

(c)

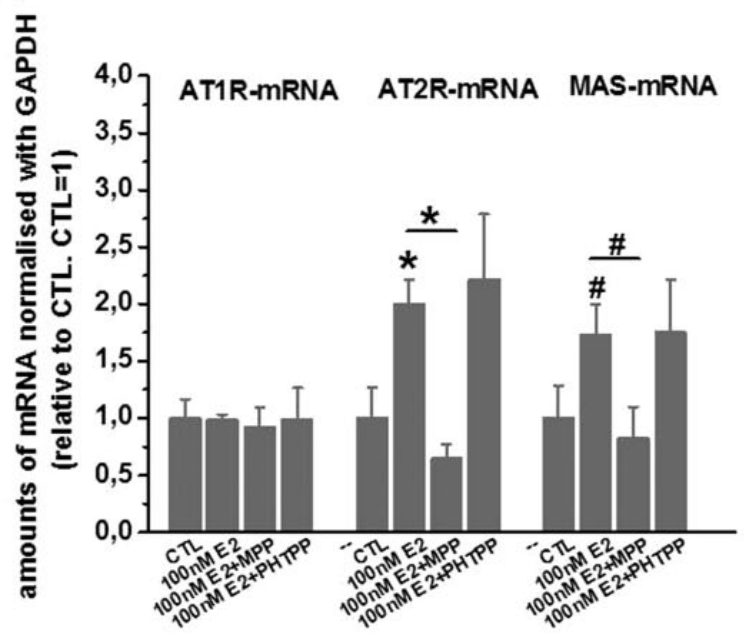

(e)

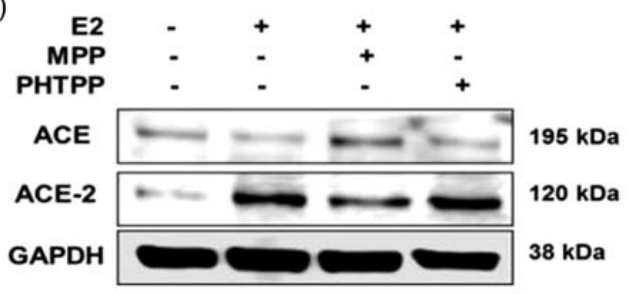

(b)

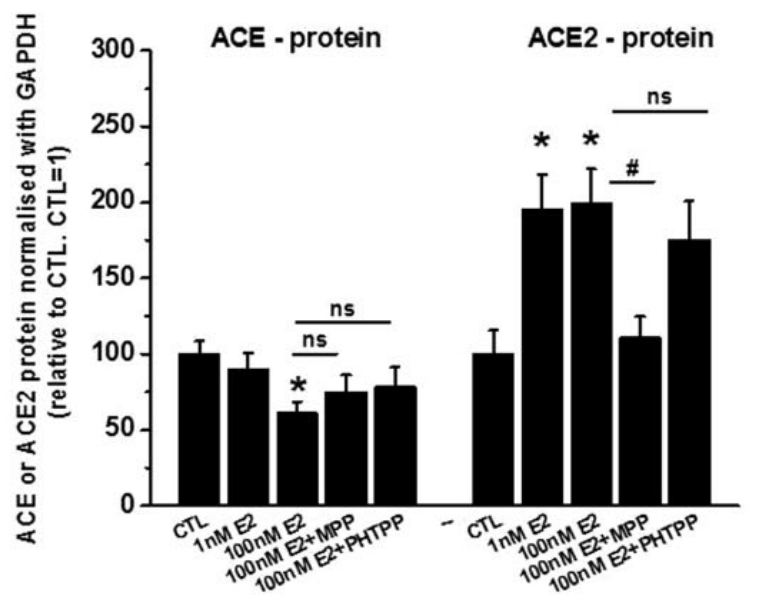

(d)

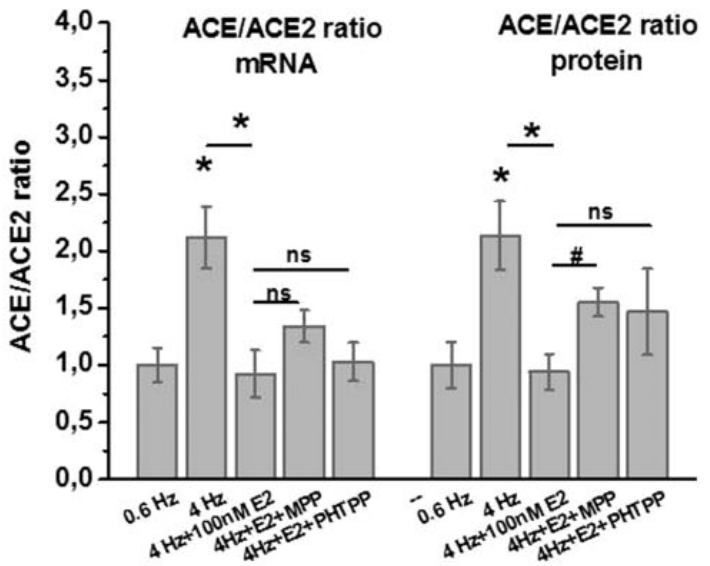

(f)

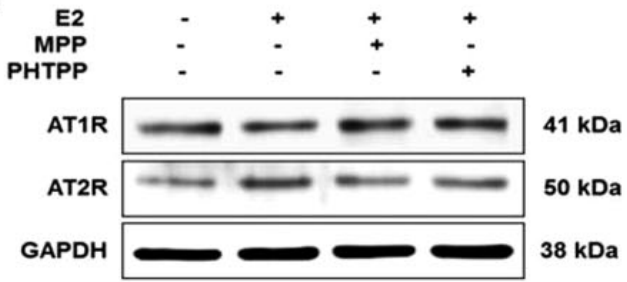

(g)

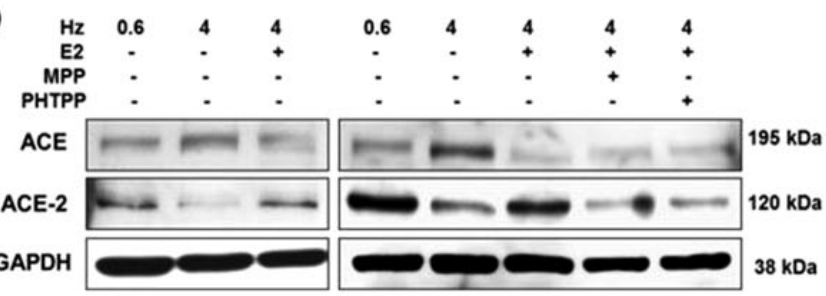

Figure 3 Effects of E2 on the expression of ACE and ACE2. At first, atrial slices were subjected to different concentrations of E2 for $24 \mathrm{~h}$. Transcriptional (a) and Western blots $(b, e)$ analysis revealed a significant downregulation of ACE expression by E2 and an increase in the ACE2 expression at the resting condition. The pretreatment with MPP, but not with PHTPP, reversed the effects of E2 on the ACE2 expression. (c, e) Analysis at the RT-qPCR elicited upregulation of AT2R and MAS receptors in the presence of E2. The AT1R is not affected by E2. (f) Representative Western blots confirmed the enhanced expression of AT2R. (d) Additionally, atrial slices were paced at $4 \mathrm{~Hz}$ in the presence of $100 \mathrm{nM}$ E2. Analysis at the RT-qPCR and protein level showed significant upregulation in the ACE/ACE2 ratio during rapid pacing $(0.6 \mathrm{~Hz}$ vs. $4.0 \mathrm{~Hz})$. The administration of E2 reduced the ACE/ACE2 ratio significantly. (g) Representative Western blots demonstrated the enhanced expression of ACE and the lowered expression of ACE2 caused by pacing and confirmed the opposite regulation by E2. Results are expressed as means \pm SEM, compared to resting control (CTL set as 1), or $0.6 \mathrm{~Hz}$ control for pacing experiments respectively. ${ }^{*} P<0.01,{ }^{\#} P<0.05$ 
Bukowska et al. Protective effects of estrogen on the aged heart 1419

(a)

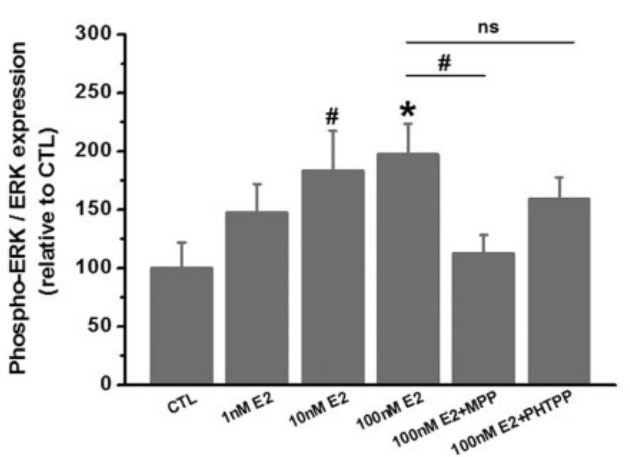

(b)

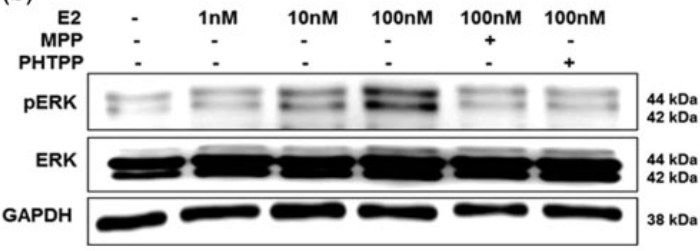

(c)

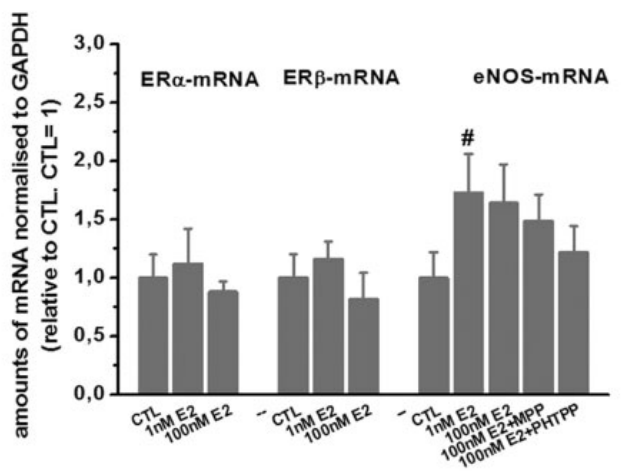

Figure 4 Protective effects of E2 on the human right atrial myocardium. The atrial tissue slices were incubated with different concentrations of E2 for $24 \mathrm{~h}$. Exposure to E2 increased the phosphorylation of ERK kinase. The pretreatment with MPP, PHTPP abolished the activation of ERK with different efficiency. (a) Quantification of the activation state was performed by densitometry. Results are expressed as means \pm SEM, compared to resting control (CTL set as 100\%). (b) Representative Western blots showed an activation of ERK by E2. (c) Effects of E2 on the amount of ER $\alpha$ - and ER $\beta$-mRNA and eNOS-mRNA. There was no significant change in the expression of both ERs. However, E2 increased the level of eNOS-mRNA. Results are expressed as means \pm SEM, compared to resting control (CTL set as 1). ${ }^{*} P<0.01,{ }^{\#} P<0.05$

reversed the inhibitory action of E2. On the contrary, the antagonist of ER $\beta$ did not influence the inhibitory action of E2 (Figure 5).

In response to rapid pacing, the expression of LOX-1 and ICAM-1 increased significantly (Figure 5). The presence of E2 largely prevented the induction of LOX-1 at the transcriptional level $(1.2 \pm 0.10$ vs. $2.2 \pm 0.2$ at $4 \mathrm{~Hz} ; n=15$; $P<0.01)$, and at the protein level $(121 \pm 12 \%$ vs. $176 \pm 18 \%$ at $4 \mathrm{~Hz} ; n=11 ; P<0.05)$. Similar inhibitory effect achieved E2 on the expression of ICAM-1-mRNA (1.1 \pm 0.1 vs. $2.0 \pm 0.3$ at $4 \mathrm{~Hz} ; n=15 ; P<0.05)$ and protein $(109 \pm 11 \%$ vs. $191 \pm 17 \%$ at $4 \mathrm{~Hz} ; n=11 ; P<0.05)$. MPP, the antagonist of $\mathrm{ER} \alpha$, reversed the inhibitory action of $\mathrm{E} 2$ on the protein expression of LOX-1 $(176 \pm 18 \%), P<0.05 ; n=4)$ and ICAM-1 (155 $\pm 4 \%, P<0.05 ; n=4)$ (Figure 5).

\section{Discussion}

The present study provides evidence that estrogen in atrial tissue is implicated in the regulation of major components of the renin-angiotensin system. Application of $17 \beta$-estradiol caused a protective shift in ACE/ACE2 ratio at the mRNA and protein level. Moreover, 17 $\beta$-estradiol reduced the atrial expression of the pro-inflammatory molecule, ICAM-1, and the expression of the pro-oxidative molecule LOX-1. These effects were accompanied by an activation of ERK kinase and increased expression of eNOS. A specific antagonist of ER $\alpha$ reversed the antiinflammatory and anti-oxidative effects of E2 in paced and non-paced atrial tissue slices.

Both ERs $\alpha$ and $\beta$ are expressed in animal and human hearts. ${ }^{5,21,22}$ Our results showed that the expression level of ER $\alpha$ mRNA and ER $\beta$ mRNA was similar between women and men and this is consistent with other studies describing no sex differences in the expression of ERs in human ${ }^{22}$ and in animal heart. ${ }^{23}$ An upregulation of ER $\alpha$ at both mRNA and protein level was associated with human aortic stenosis and with the end-stage human heart failure due to dilated cardiomyopathy. ${ }^{21}$ In both cases, ER $\alpha$ was expressed at a comparable concentration in women and in men, and the increase in ER $\alpha$ occurred in both. ${ }^{22}$ We demonstrated that the expression of ERs in human atrial slices was not changed following $24 \mathrm{~h}$ exposure to E2 treatment. Similar findings were reported by Pugach et al., ${ }^{23}$ where male and female rat cardiomyocytes were subjected to E2. These facts indicate that E2 may mediate its effects in the heart without changes in the expression level of ERs. In fact, ligand-dependent E2 signaling starts with the binding of E2 to ER. The cell-specific transcriptional response to E2 depends on multiple factors including composition of coregulatory proteins and the characteristics of the promoters of E2 responsive genes. The pattern of modulated genes also depends on whether other signaling pathways are active in the cell at the time of hormone exposure. ${ }^{24}$

In humans, estrogens are generated in several extragonadal tissues including bone chondrocytes and osteoblasts, vascular smooth muscle cells, skin, skeletal muscle, several brain regions, and the adipose tissue. ${ }^{25}$ The gonads and the adrenals express all the necessary enzymes to synthesize estrogens from cholesterol, whereas other tissues depend on precursor supply from the blood. ${ }^{26}$ Estrogens are also produced during the entire male life cycle, having an action pattern similar to that of postmenopausal women. ${ }^{27}$ Despite of low circulating levels, local estrogen concentrations may be high. Indeed, we could measure similar levels of estrogens in atrial tissue from elderly men and women. The high tissue concentration indicates the potential of paracrine, autocrine, and intracrine actions of E2 in the tissue. ${ }^{28}$ Of note, the immune-based assay used in our study does not distinguish between the active form and biologically inactive estrogen sulfates. ${ }^{29}$

The heart tissue expresses all important components of RAS required for the production of AngII. This major effector peptide of the RAS mediates its physiological and pathophysiological effects mainly through the AT1 receptor (AT1R). The stimulation of AT1R by AngII causes 
(a)

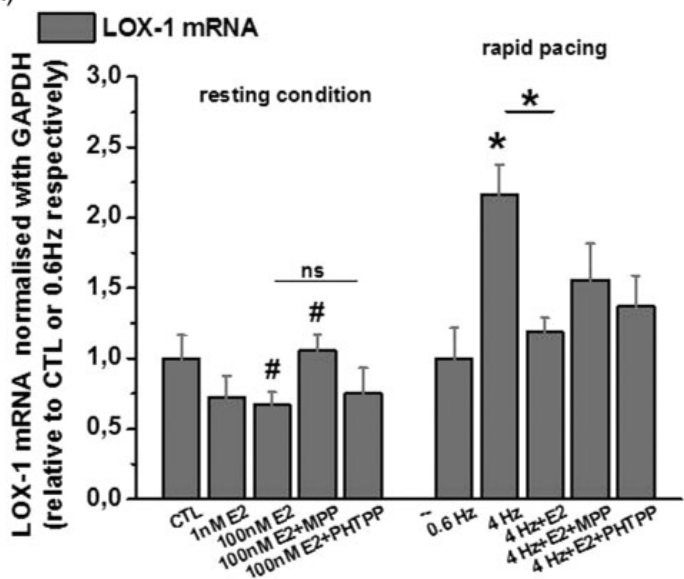

(c)

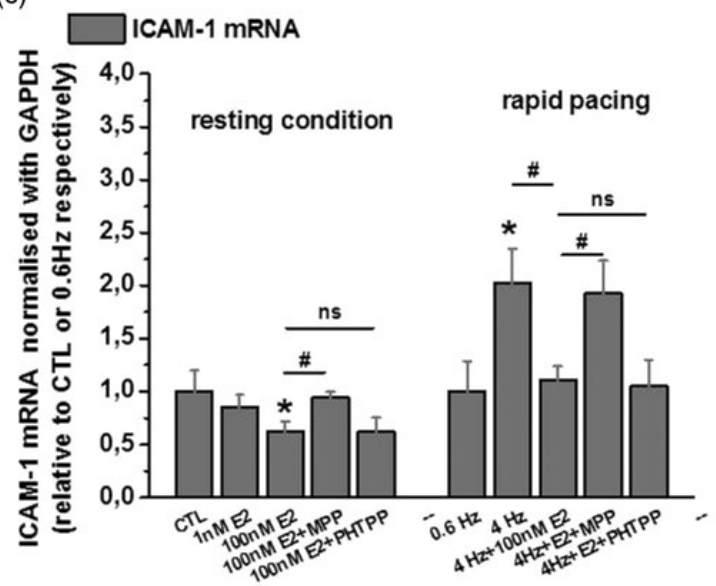

(e)

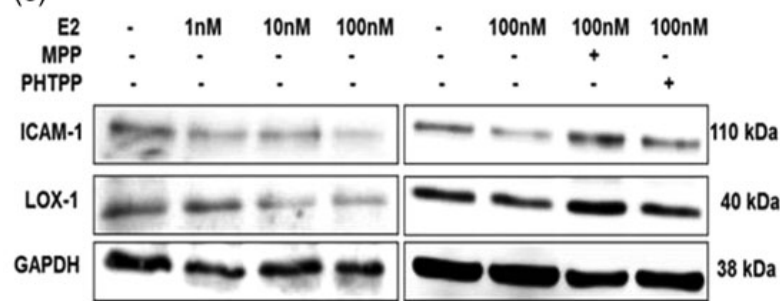

(b)

LOX-1 protein

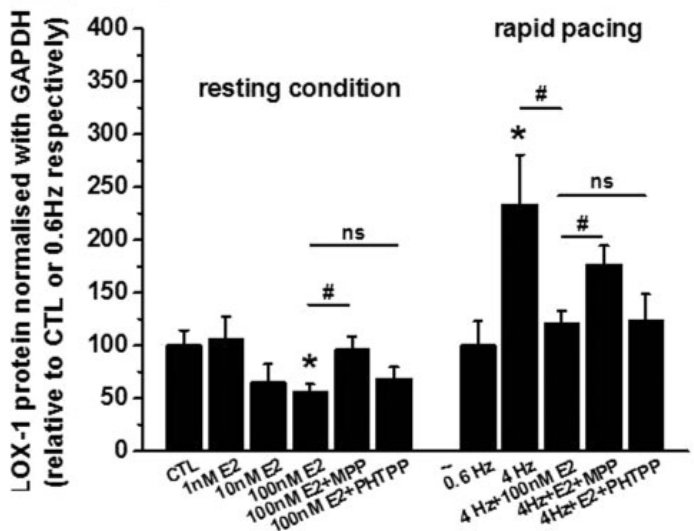

(d)
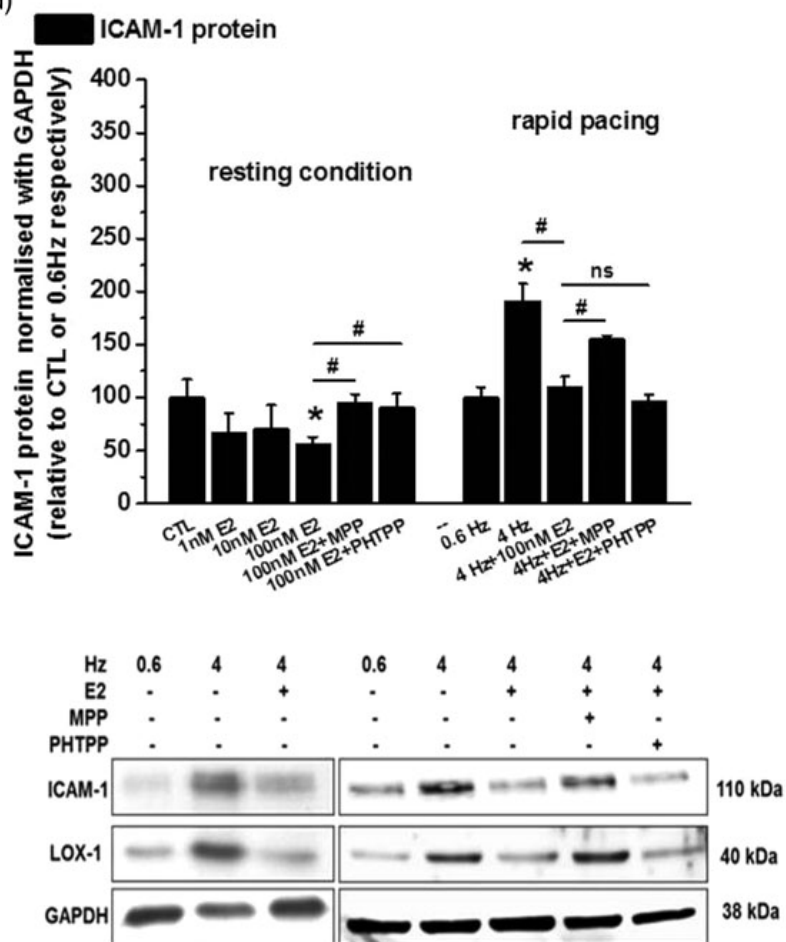

Figure 5 E2 diminished atrial expression of NF- $\kappa B$ target genes: LOX-1 and ICAM -1. Human atrial slices were exposed to E2 for $24 \mathrm{~h}$. Additionally, atrial slices were paced at $4 \mathrm{~Hz}$ in the presence of E2. The effects of MPP, PHTPP were investigated on slices treated with $100 \mathrm{nM}$ of E2. (a, c) Transcriptional analysis revealed a significant reduction of LOX-1 and ICAM-1-mRNA by E2 under resting and pacing conditions. MPP, but not PHTPP reversed effects of E2 (b, d) Quantification of the protein expression by densitometry. (e) The representative Western blots showed a downregulation of LOX-1 and ICAM-1 protein by E2. Results are expressed as means \pm SEM, compared to resting control (CTL), or $0.6 \mathrm{~Hz}$ control for pacing experiments respectively. ${ }^{*} P<0.01$, ${ }^{\#} P<0.05$

vasoconstriction, hypertrophy, fibrosis, increased production of oxygen free radicals, and apoptosis. ${ }^{30}$ While ACE plays a pivotal role in the generation of AngII, ACE2 exhibits high catalytic activity for the conversion of AngII to Ang-(1-7). ${ }^{31}$ There is few documented evidence supporting estrogen's regulatory properties toward components of RAS. Animal studies showed that chronic E2 replacement reduces ACE activity and mRNA levels in kidney and aorta. $^{32-34}$ In agreement with these findings, we show that E2 diminishes ACE mRNA in human right atria. The mechanisms underlying these effects of E2 on the ACE expression remain unclear due to the absence of a consensus estrogen response element in the ACE promoter. $^{35-37}$
It was suggested, therefore, that the effects are indirect and occur in response to the local, tissue-specific environment. Other studies have reported that E2 modulates the expression of ACE2. Accordingly, ACE2 mRNA and activity were increased in the kidney and uterus of pregnant animals. $^{38-41}$ In line with these results, Shenoy et al. ${ }^{42}$ demonstrated increased protein levels of ACE2 in the left ventricle in DOCA animals (model of hypertension) receiving high-dose $\mathrm{E} 2$ replacement. The increase in the activity of ACE2 might attenuate the RAS system by inactivating AngII and enhancing the production of cardioprotective Ang-(1-7). The alternative ACE2/Ang-(1-7) axis of the RAS represents an endogenous counter-regulatory axis. ${ }^{43}$ 
Our study indicates that E2 via down-regulation of ACE and simultaneous induction of ACE2 might modify the atrial responses to stress and could contribute to antiarrhythmic effects. The activated classical RAS and, in particular, increased AngII levels are key mediators of atrial tissue remodeling that might facilitate the development of atrial arrhythmia, like AF. Indeed, it has been already shown that ACE inhibitors reduce the incidence of AF in patients with heart disease. ${ }^{44}$

Earlier work provided evidence for the existence of gender-dependent differences in cardiac ACE expression with the enhanced cardiac ACE/RAS axis in male compared with female mice. ${ }^{45}$ In females, the balance is shifted towards the alternative ACE2/Ang(1-7)/MasR and AT(2)R pathways. ${ }^{12}$ This could explain the obvious gender-specific differences in the prevalence of cardiovascular pathologies like myocardial hypertrophy, and cardiac fibrosis. ${ }^{46}$ With aging, this cardiovascular protection in women is lost and this may be related to loss of E2 in postmenopause and the possible shift from the protecting ACE2/RAS axis into the classical ACE/RAS pathways. Interestingly, the ACE activity is decreased in the serum of postmenopausal women on hormone replacement therapy. ${ }^{47}$

E2 exerts anti-inflammatory effects. ${ }^{48-51}$ Caulin-Glaser et al. ${ }^{48}$ showed that the pre-treatment of human endothelial cells with E2 strongly inhibited IL-1-mediated upregulation of the adhesion molecules E-selectin, ICAM-1, and VCAM-1. This inhibition was abrogated by an E2 antagonist, demonstrating a specific, ER-mediated nature of this effect. Similar to this study, Simoncini et al. ${ }^{50}$ showed that E2 decreased LPS-induced VCAM-1 mRNA and protein expression. Gel-shift analyses revealed that E2 inhibited LPS-induced activation of transcription factors NF- $\kappa B$ and AP-1. In cardiomyocytes, Pelzer et al. ${ }^{51}$ demonstrated that E2 inhibited staurosporine-induced p65/p50 DNA binding.

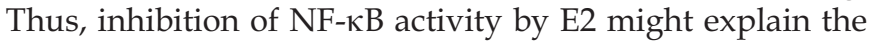
blunted expression of NF- $\mathrm{KB}$ target genes like LOX1 and ICAM-1 in human atrial myocardium and strongly support the anti-inflammatory and antioxidant effects, respectively. It has also been reported that E2 therapy leads to an increase in total serum antioxidant capacity resulting in an improvement in the antioxidant status in women. ${ }^{52}$ Recently, Campos et al. ${ }^{53,54}$ reported that the administration of E2 decreased cardiac oxidative stress in ovariectomized Wistar rats $(\mathrm{Ovx})$. E2 significantly downregulated the ventricular level of reactive oxygen species in the treated groups compared to the Ovx group. In the present study, we documented for the first time a significant decrease in atrial expression of LOX-1 mRNA and protein. LOX-1 is an indicator of a redox imbalance. Results of our group demonstrated the involvement of LOX-1 in the oxidative state within the right atrium in patients with $\mathrm{AF}^{55}$ Importantly, increased "oxidative stress" contributes to a pro-inflammatory and prothrombotic state of the atrial endomyocardium during AF. Obviously, future experiments should elucidate the in vivo relevance of E2 on atrial protection mechanisms.

The two major clinical consequences of AF are thromboembolic events and heart failure. Clinical and animal studies showed the existence of sex differences in the development of myocardial hypertrophy and heart failure (HF). ${ }^{22,56-58}$ Women with HF have a better survival rate than men. In most models, death from HF occurs earlier in male than in female animals. This suggests that estrogen prevents or at least slows down the development of HF. In fact, users of hormone therapy had less myocardial hypertrophy and heart failure. Despite of promising results observed in clinical and animal studies, effects of E2 on the heart tissue are still incompletely understood and require a better basic understanding of the underlying mechanisms. At present, there is no therapeutic exploitation of this potential approach. The findings that E2 replacement in postmenopausal women increased the cardiovascular risk have evoked more cautions in applying sex steroids as therapeutics. However, better timing of E2 administration as well as an introduction of novel therapeutic approaches with specific ER agonists could offer new perspectives in the therapy of heart diseases. Therefore, further extensive studies are prerequisite for therapeutic application of E2, or selective ER modulators to slow down the remodeling processes in AF patients.

\section{Study limitations}

The present study has several limitations. First of all, the human tissue slices were prepared from biopsies obtained only from right appendages. Second, patients participated in the study suffered also from concomitant diseases as coronary artery disease and/or hypertension and/or diabetes mellitus. Thus, in contrast to animal studies, no healthy controls were used. Third, there were multiple drugs involved in the treatment of patients in this study. Some drugs exert pleiotropic actions beyond their main pharmacological targets. So far, it has been reported that statin (lipophilic forms) upregulates ER $\alpha$ in osteoblasts, and captopril, an ACE inhibitor, downregulates the protein level of ER in ductual carcinoma cell lines. ${ }^{59,60}$ Effects of these drugs on the cardiac ERs have not been investigated yet. However, this knowledge would be helpful to interpret the effects of E2 in atrial tissue. Forth, the high concentration of E2 administrated in "in vitro" experiments might rouse reasonable skepticism of the "in vivo" relevance. It is important to mention that the thickness of atrial slices is about $350 \mu \mathrm{m}$ and represent about 20 layers of cells. The majority of studies subjected to effects of E2 worked with the concentration of $10 \mathrm{nM}$. Finally, we were not able to determine the level of testosterone in the investigated tissue samples from aged men due to the limited size of material obtained from surgery. Thus, any interaction between the low levels of testosterone and the ERs in atrial tissue from elderly man could not be shown.

\section{Conclusions}

The results demonstrated in this study imply that E2 modulates the expression of important components of the atrial RAS, ACE and ACE2. We clearly showed the shift from ACE to ACE2 expression, and thus from the classical ACE/AngII/AT1R axis to the alternative ACE2/Ang-(1-7) RAS axis caused in presence of E2. Moreover, the exposure of atrial tissue to E2 elicited anti-inflammatory and 
anti-oxidative properties. These data help to understand the beneficial modulation by E2 at the level of molecular biology in atrial myocardium from elderly men.

Authors' contributions: AG, AB, UL, CW, IK, AGA were involved in the study design; $\mathrm{LS}, \mathrm{AB}, \mathrm{PB}$ conducted experiments; LS, AB were engaged in molecular and biochemical data acquisition and statistical analysis; IK, LS, PB were involved in ethic procedures and sampling of human materials; SW performed microscopic analysis; JH, BI performed and evaluated level of $\mathrm{E} 2$ in tissue; $\mathrm{AB}, \mathrm{AG}$ wrote the manuscript; CW, UL, AGA, SW, LS, JH, .I made critical revision of the manuscript for key intellectual content; AG, UL handled funding and supervision. All authors read and approved the final manuscript.

\section{ACKNOWLEDGMENTS}

We thank Marianne Blichmann for her excellent technical assistance. The study was supported by the European Union Seventh Framework Programme (FP7/ 2007-2013) under Grant Agreement HEALTH-F2-2010-261057.

\section{DECLARATION OF CONFLICTING INTERESTS}

The author(s) declared no potential conflicts of interest with respect to the research, authorship, and/or publication of this article.

\section{REFERENCES}

1. Knowlton AA, Lee AR. Oestrogen and the cardiovascular system. Pharmacol Ther 2012;135:54-70

2. Bjornstrom L, Sjoberg M. Mechanisms of oestrogen receptor signaling: convergence of genomic and nongenomic actions on target genes. Mol Endocrinol 2005;19:833-42

3. Ueda K, Karas RH. Emerging evidence of the importance of rapid, nonnuclear oestrogen receptor signaling in the cardiovascular system. Steroids 2013;7:589-96

4. Simoncini T, Varone G, Fornari L, Mannella P, Luisi M, Labrie F, Genazzani AR. Genomic and nongenomic mechanisms of nitric oxide synthesis induction in humanendothelial cells by a fourth-generation selective oestrogen receptor modulator. Endocrinology 2002;143:2052-61

5. Grohé C, Kahlert S, Löbbert K, Stimpel M, Karas R, Vetter H, Neyses L. Cardiac myocytes and fibroblasts contain functional oestrogen receptors. FEBS Lett 1997;416:107-12

6. Nuedling S, Kahlert S, Loebbert K, Doevendans PA, Meyer R, Vetter H, Grohé C. 17 Beta-oestradiol stimulates expression of endothelial and inducible NO synthase in rat myocardium in-vitro and in-vivo. Cardiovasc Res 1999:43:666-74

7. de Jager T, Pelzer T, Müller-Botz S, Imam A, Muck J, Neyses L. Mechanisms of oestrogen receptor action in the myocardium, Rapid gene activation via the ERK1/2 pathway and serum response elements. J Biol Chem 2001;276:27873-80

8. Patten RD, Pourati I, Aronovitz MJ, Baur J, Celestin F, Chen X, Michael A, Haq S, Nuedling S, Grohe C, Force T, Mendelsohn ME, Karas RH. 17betaoestradiol reduces cardiomyocyte apoptosis in vivo and in vitro via activation of phospho-inositide-3 kinase/Akt signaling. Circ Res 2004;9:692-9

9. Donaldson C, Eder S, Baker C, Aronovitz MJ, Weiss AD, Hall-Porter M, Wang F, Ackerman A, Karas RH, Molkentin JD, Patten RD. Oestrogen attenuates left ventricular and cardiomyocyte hypertrophy by an oestrogen receptor-dependent pathway that increases calcineurin degradation. Circ Res 2009;104:265-75
10. Fischer M, Baessler A, Schunkert H. Renin angiotensin system and gender differences in the cardiovascular system. Cardiovasc Res 2002;53:672-7

11. Bechtloff R, Goette A, Bukowska A, Kähne T, Peters B, Huth C, Wolke C, Lendeckel U. Gender and age-dependent differences in the bradykinindegradation within the pericardial fluid of patients with coronary artery disease. Int J Cardiol 2011;146:164-70

12. Hilliard LM, Sampson AK, Brown RD, Denton KM. The "his and hers" of the renin angiotensin system. Curr Hypertens Rep 2013;15:71-9

13. Goette A, Bukowska A, Lendeckel U, Erxleben M, Hammwöhner M, Strugala D, Pfeiffenberger J, Röhl FW, Huth C, Ebert MP, Klein HU, Röcken C. Angiotensin II receptor blockade reduces tachycardiainduced atrial adhesion molecule expression. Circulation 2008;117:732-42

14. Goette A, Ittenson A, Hoffmanns P, Reek S, Hartung W, Klein H, Ansorge S, Geller JC. Increased expression of P-selectin in patients with chronic atrial fibrillation. Pacing Clin Electrophysiol 2000;23(11 Pt 2): 1872-5

15. Cardin S, Li D, Thorin-Trescases N, Leung TK, Thorin E, Nattel S. Evolution of the atrial fibrillation substrate in experimental congestive heart failure: angiotensin-dependent and -independent pathways. Cardiovasc Res 2003;60:315-25

16. Tsai CT, Lai LP, Hwang JJ, Chen WP, Chiang FT, Hsu KL, Tseng CD, Tseng YZ, Lin JL. Renin-angiotensin system component expression in the HL-1 atrial cell line and in a pig model of atrial fibrillation. J Hypertens 2008;26:570-82

17. Goette A, Staack T, Rocken C, Arndt M, Geller JC, Huth C, Ansorge S, Klein HU, Lendeckel U. Increased expression of extracellular signalregulated kinase and angiotensin-converting enzyme in human atria during atrial fibrillation. J Am Coll Cardiol 2000;35:1669-77

18. Bukowska A, Zacharias I, Weinert S, Skopp K, Hartmann C, Huth C, Goette A. Coagulation factor Xa induces an inflammatory signalling by activation of protease-activated receptors in human atrial tissue. Eur $J$ Pharmacol 2013;718:114-23

19. Bussek A, Wettwer E, Christ T, Lohmann H, Camelliti P, Ravens U. Tissue slices from adult mammalian hearts as a model for pharmacological drug testing. Cell Physiol Biochem 2009;24:527-36

20. Livak KJ, Schmittgen TD. Analysis of relative gene expression data using real-time quantitative PCR and the 2(-Delta Delta $\mathrm{C}(\mathrm{T})$ ) method. Methods 2001;25:402-8

21. Nordmeyer J, Eder S, Mahmoodzadeh S, Martus P, Fielitz J, Bass J, Bethke N, Zurbrügg HR, Pregla R, Hetzer R, Regitz-Zagrosek V. Upregulation of myocardialestrogen receptors in human aortic stenosis. Circulation 2004;110:3270-5

22. Mahmoodzadeh S, Eder S, Nordmeyer J, Ehler E, Huber O, Martus P, Weiske J, Pregla R, Hetzer R, Regitz-Zagrosek V. Estrogen receptor alpha up-regulation and redistribution in human heart failure. FASEB $J$ 2006;20:926-34

23. Pugach EK, Blenck CL, Dragavon JM, Langer SJ, Leinwand LA. Estrogen receptor profiling and activity in cardiac myocytes. Mol Cell Endocrinol 2016;431:62-70

24. Heldring N, Pike A, Andersson S, Matthews J, Cheng G, Hartman J, Tujague M, Ström A, Treuter E, Warner M, Gustafsson JA. Estrogen receptors: how do theysignal and what are their targets. Physiol Rev 2007;87:905-31

25. Monteiro R, Teixeira D, Calhau C. Estrogen signaling in metabolic inflammation. Mediators Inflamm 2014;2014:615917

26. Labrie F, Bélanger A, Luu-The V, Labrie C, Simard J, Cusan L, Gomez JL, Candas B. DHEA and the intracrine formation of androgens and estrogens in peripheral target tissues: its role during aging. Steroids 1998;63:322-8

27. Simpson ER, Clyne C, Rubin G, Boon WC, Robertson K, Britt K, Speed C, Jones M. Aromatase - a brief overview. Annu Rev Physiol 2002;64:93-127

28. Simpson ER. Sources of estrogen and their importance. J Steroid Biochem Mol Biol 2003;86:225-30

29. Mauvais-Jarvis F, Clegg DJ, Hevener AL. The role of estrogens in control of energy balance and glucose homeostasis. Endocrine Rev 2013;34:309-38 
30. Paradis P, Dali-Youcef N, Paradis FW, Thibault G, Nemer M. Overexpression of angiotensin II type I receptor in cardiomyocytes induces cardiac hypertrophy and remodelling. Proc Natl Acad Sci U S A 2000;97:931-6

31. Shaltout HA, Westwood BM, Averill DB, Ferrario CM, Figueroa JP, Diz DI, Rose JC, Chappell MC. Angiotensin metabolism in renal proximal tubules, urine, and serum of sheep: evidence for ACE2-dependent processing of angiotensin II. Am J Physiol Renal Physiol 2007;292:F82-91

32. Brosnihan KB, Senanayake PS, Li P, Ferrario CM. Bi-directional actions of oestrogen on the renin-angiotensin system. Braz J Med Biol Res 1999;32:373-81

33. Gallagher PE, Li P, Lenhart JR, Chappell MC, Brosnihan KB. Oestrogen regulation of angiotensin-converting enzyme mRNA. Hypertension 1999;33:323-8

34. Wu G, Fang YZ, Yang S, Lupton JR, Turner ND. Glutathione metabolism and its implications for health. J Nutrition 2004;134:489-92

35. Goraya TY, Kessler SP, Kumar RS, Douglas J, Sen GC. Identification of positive and negative transcriptional regulatory elements of the rabbit angiotensin-converting enzyme gene. Nucleic Acids Res 1994;22:1194-201

36. Howard T, Balogh R, Overbeek P, Bernstein KE. Sperm-specific expression of angiotensin-converting enzyme (ACE) is mediated by a 91-basepair promoter containing a CRE-like element. Mol Cell Biol 1993;13:18-27

37. Shai SY, Langford KG, Martin BM, Bernstein KE. Genomic DNA 59 to the mouse and human angiotensin-converting enzyme genes contains two distinct regions of conserved sequence. Biochem Biophys Res Commun 1990;167:1128-33

38. Zhou Y, Sun Z, Means AR, Sassone-Corsi P, Bernstein KE. cAMP response element modulator tau is a positive regulator of testis angiotensin converting enzyme transcription. Proc Natl Acad Sci USA 1996;93:12262-6

39. Joyner J, Neves LA, Granger JP, Alexander BT, Merrill DC, Chappell MC, Ferrario CM, Davis WP, Brosnihan KB. Temporal-spatial expression of ANG-(1-7) and angiotensin-converting enzyme 2 in the kidney of normal and hypertensive pregnant rats. Am J Physiol Regul Integr Comp Physiol 2007;293:R169-77

40. Neves LA, Stovall K, Joyner J, Valdés G, Gallagher PE, Ferrario CM, Merrill DC, Brosnihan KB. ACE2 and ANG-(1-7) in the rat uterus during early and late gestation. Am J Physiol Regul Integr Comp Physiol 2008;294R:151-61

41. Ji H, Menini S, Zheng W, Pesce C, Wu X, Sandberg K. Role of angiotensin-converting enzyme 2 and angiotensin(1-7) in 17 beta-ooestradiol regulation of renal pathology in renal wrap hypertension in rats. Exp Physiol 2008;93:648-57

42. Shenoy V, Grobe JL, Qi Y, Ferreira AJ, Fraga-Silva RA, Collamat G, Bruce E, Katovich MJ. 17beta-Oestradiol modulates local cardiac reninangiotensin system to prevent cardiac remodeling in the DOCA-salt model of hypertension in rats. Peptides 2009;30:2309-15

43. Ferreira AJ, Murça TM, Fraga-Silva RA, Castro CH, Raizada MK, Santos RA. New cardiovascular and pulmonary therapeutic strategies based on the Angiotensin-converting enzyme 2/angiotensin-(1-7)/mas receptor axis. Int J Hypertens 2012;2012:147825

44. Vermes E, Tardif JC, Bourassa MG, Racine N, Levesque S, White M, Guerra PG, Ducharme A. Enalapril decreases the incidence of atrial fibrillation in patients with left ventricular dysfunction: insight from the Studies Of Left Ventricular Dysfunction (SOLVD) trials. Circulation 2003;107:2926-31
45. Freshour JR, Chase SE, Vikstrom KL. Gender differences in cardiac ACE expression are normalized in androgen-deprived male mice. Am J Physiol Heart Circ Physiol 2002;283:H1997-2003

46. Sadoshima J, Xu Y, Slayter HS, Izumo S. Autocrine release of angiotensin II mediates stretch-induced hypertrophy of cardiac myocytes in vitro. Cell 1993;75:977-84

47. Proudler AJ, Ahmed AI, Crook D, Fogelman I, Rymer JM, Stevenson JC. Hormone replacement therapy and serum angiotensin-convertingenzyme activity in postmenopausal women. Lancet 1995;346:89-90

48. Caulin-Glaser T, Watson CA, Pardi R, Bender JR. Effects of 17betaoestradiol on cytokine-induced endothelial cell adhesion molecule expression. J Clin Invest 1996;98:36-42

49. Pfeilschifter J, Köditz R, Pfohl M, Schatz H. Changes in proinflammatory cytokine activity after menopause. Endocr Rev 2002;23:90-119

50. Simoncini T, Maffei S, Basta G, Barsacchi G, Genazzani AR, Liao JK, De Caterina R. Oestrogens and glucocorticoids inhibit endothelial vascular cell adhesion molecule-1 expression by different transcriptional mechanisms. Circ Res 2000;87:19-25

51. Pelzer T, Neumann M, de Jager T, Jazbutyte V, Neyses L. Oestrogen effects in the myocardium: inhibition of NF-kappaB DNA binding by oestrogen receptor-alpha and -beta. Biochem Biophys Res Commun 2000;286:1153-7

52. Darabi M, Ani M, Movahedian A, Zarean E, Panjehpou M, Rabbani M Effect of hormone replacement therapy on total serum anti-oxidant potential and oxidized ldl/ß2-glycoprotein i complexes in postmenopausal women. Endocrine J 2010;57:1029-34

53. Campos C, Casali KR, Baraldi D, Conzatti A, Araújo AS, Khaper N, Llesuy S, Rigatto K, Belló-Klein A. Efficacy of a low dose of oestrogen on antioxidant defenses and heart rate variability. Oxid Med Cell Longev 2014;2014:218749

54. Campos C, Sartorio CL, Casali KR, Fernandes RO, Llesuy S, da Rosa Araujo AS, Belló-Klein A, Rigatto KV. Low dose oestrogen is as effective as high dose treatment in rats with postmenopausal hypertension. J Cardiovasc Pharmacol 2014;63:144-51

55. Bukowska A, Schild L, Keilhoff G, Hirte D, Neumann M, Gardemann A, Neumann KH, Röhl FW, Huth C, Goette A, Lendeckel U. Mitochondrial dysfunction and redox signaling in atrial tachyarrhythmia. Exp Biol Med 2008;233:558-74

56. Levy D, Kenchaiah S, Larson MG, Benjamin EJ, Kupka MJ, Ho KK, Murabito JM, Vasan RS. Long-term trends in the incidence of and survival with heart failure. N Engl J Med 2002;347:1397-402

57. Du XJ. Gender modulates cardiac phenotype development in genetically modified mice. Cardiovasc Res 2004;63:510-9

58. Regitz-Zagrosek V, Oertelt-Prigione S, Seeland U, Hetzer R. Sex and gender differences in myocardial hypertrophy and heart failure. Circ J 2010;74:1265-73

59. Park JB, Zhang H, Lin CY, Chung CP, Byun Y, Park YS, Yang VC. Simvastatin maintains osteoblastic viability while promoting differentiation by partially regulating the expressions of estrogen receptors $\alpha$. J Surg Res 2012;174:278-83

60. Small W Jr, Molteni A, Kim YT, Taylor JM, Chen Z, Ward WF. Captopril modulates hormone receptor concentration and inhibits proliferation of human mammary ductal carcinoma cells in culture. Breast Cancer Res Treat 1997;44:217-24 